\title{
The Economic Efficiency of Wheat Farms in Baghdad Province (Abu-Ghraib), (In Iraq - 2015)
}

\author{
Hawraa Jaafer Mohammed \\ Agricultural economics Department, college of Agriculture, University of Baghdad.
}

\begin{abstract}
Wheat is considered as a strategic crop and it occupies economic position in most of the world countries due to its nutrition importance, it is a food resource of more than $35 \%$ of world population and it is considered the most importance cereal crop that covered the largest area grown by wheat on the earth surface in spite of its importance, wheat production suffers a clear turbulence because farmers don't go on planting wheat due to the gated net return reduction resulted by not using the new technical and scientific tools in farming besides bad management which is considered in general as the important limitation factor in agriculture in Iraq and in wheat cultivation in specific case. ,Abu-Graib region was chosen as an applicable model in this study. The data was collected by using questionnaires that were given to 72 farmers in AbuGhraib region in agricultural season 2014-2015, and it formed 3.42\% of wheat farms in the studied society and 2103 farmers. The research subjected analysis of revenues and costs items to study the economic efficiency by application of economic efficiency criterias and determine the technical efficiency on concept of the randomized border analysis after determination of the production logarithmic function by using Frontier program., The result showed that all the farms achieved valuable economic income when the economic efficiency criterias were applied .Results showed values, (profit, income net, farming return to Labor returns to farming management incomes and Benefit Cost ratio were (492246.88, 470825.88, 462078.8, 29568.3 and 4.6 ) thousand dinars respectively. The best period to recover the capital was in the area farm group 31 donums and more, It reached to 0.20 .at break - even point was 16.12 tons and there was positive relation between rising income level and land area.The technical efficiency was determined according to stochastic frontier analysis model after determinations of transcendence logarithmic function by using Frontier program which pointed that the work and the capital had positive effect on yield production quantity when their increase in 1\% ratio resulted to increase production to $0.36 \%$ and $0.64 \%$ respectively. The technical efficiency was $99 \%$ and this means that the farmers can increase the production to $1 \%$ without increase in the used economic resources.
\end{abstract}

Key words: The Stochastic Frontier analysis , economic efficiency, wheat.

\section{Introduction}

The economists and the agricultural systems aim is improvement of farm performance and Iraq is one of the countries that suffers bad usage of the available resources which caused decline of the economic efficiency. Studying the economic efficiency is important in determination of the production problems and directs the production units (Fars,2006,37). Efficiency analysis can be used in determination the general interactions in agricultural productivity and farm income (Soils et al,2009:203).The economic efficiency includes both of the technical efficiency and the Allocativ efficiency (Farrel,1957:253).

Wheat is considered as strategic crop in the world for its nutrition importance ,it is food source for more than $35 \%$ of world population and it is the most importance crop that covers large cultivated area on the earth surface compared with other crops and the bread that done from its flour contains 12-17\% protein,76-78\% starch and 1.2-1.5\% fats (wheat cultivation technology,2011). Wheat is grown in area close to 225 million hectare around the world , and India is the first in wheat cultivated area (28.4 million hectares) compared with world countries followed by China and USA. The cultivated area does not reflect the production and the arrangement of countries according to their productivity were China with 704.1 million tons, then India and USA . On the Arabic countries level, Egypt was the first in productivity with 8.4 million tons followed by Syria with 3.9 million tons (FAO,2011). In Iraq, the wheat production was 2.8 million tons in 2011 and 4.2 million tons in 2013 (agricultural statistics ,planning and follow-up department, Ministry of Agriculture, 2013). It is slight quantity compared with the world production due to the bad use of the productivity resources according to the economic criterias and in order to reach to higher levels in wheat production and achieving the important developing aims that are food security achievement, so, there is need to study the most important indicators that may be used to know management efficiency in order to direct the economic resources. 


\section{Research Problem}

Decline Iraq production of the strategic crops generally and wheat crop especially in spite of support policies that are given by the government to the farmers. One of the production decline reasons is the difficulty of getting the ideal mixture of the economic resources and that resulted to farm income level decline and then do not achieve an economic efficiency in required level.

\section{Research aim}

1- Study the economic merit of wheat crop cultivation by application of economic efficiency criterias by using randomized sample of 72 wheat crop farmers in Abu-Graib in the agricultural season (2014-2015). The sample represents $3.42 \%$ of wheat crop farmers in the study area.

2- Determine transcendence logarithmic production function according to randomized analysis model and using it in technical efficiency calculation.

\section{Research hypotheses}

The research hypotheses were that wheat farms suffers production problems that gave profit decline and no advantages from wheat cultivation from economical point of view .These caused to non-expanded wishes in increasing wheat cultivation in Iraq.

\section{Data resources}

The data were got by using questionnaire prepared to this purpose and filled by randomized personal meeting of sample of wheat farmers in Baghdad governance, Abu-Graib region in the 2014-2015 season. thequestionnaire included 72 farmers using 1719 donums. The research used numbers of secondary data that put by planning - follow-up department, Ministry of Agriculture.

\section{Materials And Methods}

The interest of the economic efficiency on different production levels is considered as biotic necessity in how to direct and coordinate the different activities efficiently .it is necessary to know the productivity units efficiency in direction of the economic resources that may be defined as use of wealth resources in such a way that allows to get bigger production with the last productivity costs and the second of the last production with less productivity costs ( Al-Izi, $1988 ; 78$ ). The yield in the two cases is increasing net of the verified incomes, it means getting large amount of net income because the agricultural growth does not checks unless increasing farm net income was done often covering the farm family requirements of goods and services (Al-Samurai, 1984. 88). The aim of the agricultural producer is getting the maximum possible income, as getting a maximum farming income. The important thing that distinguish a project compared with other project is the management quality that may be measured by the efficiency degree of resources uses that is called farming management advantages that may be calculated from the following relation :returns to farming Labor - family Labor value). The returns to farming Labor are equal to the net farming income minus the interest on the capital (Al-Izi, 2002, 245-250). There are another criteria of the economic efficiency such as Pay Back Period of capital which is the period of time getting covered the investigation costs which equal total costs divided by net farming income, the Benefit Cost ratio is equal the total revenues divided by total costs (AL-Qaisi , 2009,71), if its value was more than one, it means a money successful of the productivity unit. Break - even Point is considered as from the used criteria in analysis the relation between the production size and costs profits are production quantity at naturalization point and they may be determined by using the following relation :( Donna,C.S.,2009).

(Total fixed costs (TFC)/(price of production unit (PY) - Average of variable costs(AVC)The research depends on the quantities method to achieve its aims, determination of function of productivity transcendence according to randomized border way by using three methods, ordinary small squares, corrected small squares and maximum possibility method by using frontier program.

\section{Data analyses and discussion of results:}

The sample was divided into three groups to allow to analysis production and costs items. As it is shown in table -1- that explains the possession part of group one (1-15) donum is prevailing and it included $44 \%$ of the farmers included in this study. For the cultivated area, the dominated group that includes in it $57 \%$ of the cultivated area is the third (31 donum and more) followed by the second group (16-30) donum. As it is shown that most of the used areas can absorb the new technology from size and ability of bearing the costs accompanying to it. 
The economic efficiency of wheat farms in Baghdad Province (Abu-Ghraib),(In Iraq - 2015)

Table -1- The total possession, farmers number and agricultural workers number of the research sample

\begin{tabular}{|l|l|l|l|l|l|l|}
\hline Possession donum & $\begin{array}{l}\text { Number of } \\
\text { farmers }\end{array}$ & $\begin{array}{l}\text { Percentage } \\
\%\end{array}$ & $\begin{array}{l}\text { Cultivated area } \\
\text { (donum) }\end{array}$ & $\begin{array}{l}\text { Area } \\
\text { percentage }\end{array}$ & $\begin{array}{l}\text { Number } \\
\text { workers } \\
\text { agricultural }\end{array}$ & $\begin{array}{l}\text { of } \\
\text { in }\end{array}$ \\
\hline $15-1$ & 32 & 44.4 & 240 & 14 & 295 & 63.44 \\
\hline $30-16$ & 19 & 26.4 & 499 & 29 & 96 & 20.65 \\
\hline 31 and more & 21 & 29.2 & 980 & 57 & 74 & 15.91 \\
\hline total & 72 & 100 & 1719 & 100 & 465 & 100 \\
\hline
\end{tabular}

Source: Done by the researcher depending on the questionnaires .

1- First : production and costs the production : total production in the research sample was 900.55 tons of wheat and the third group of possession included the larger ratio of production that was 506 ton (equal 56\% of sample production). That was due to the large cultivated areas that included in this group and made it capable of getting the mass production advantages, it followed by the second group and first group. The donum productivity was high in the third group and reached $516 \mathrm{~kg} /$ donum, then the second and the first, this productivity Is considered high on country level but it is low compared with world level. The research sample achieved total incomes (the exported wheat grains revenue and price of hay), the third group recorded the highest revenue while the first group recorded higher averagerevenuedonumreached 400.73 thousand dinars,Table-2- .

Table 2. Total of production, productivity and revenues of wheat crop in the research sample .

\begin{tabular}{|l|l|l|l|l|l|l|}
\hline Groups(donum) & $\begin{array}{l}\text { Production } \\
\text { quantity (ton) }\end{array}$ & $\begin{array}{l}\text { The cultivated } \\
\text { area } \\
\text { (donum) }\end{array}$ & $\begin{array}{l}\text { The } \\
\text { productivity(kg/donum) }\end{array}$ & $\begin{array}{l}\text { revenues(thousand } \\
\text { dinar) }\end{array}$ & $\begin{array}{l}\text { Average } \\
\text { revenue } \\
\text { donum }\end{array}$ & $\begin{array}{l}\text { Average } \\
\text { of } \\
\text { revenue } \\
\text { Ton }\end{array}$ \\
\hline $15-1$ & 128.00 & 240 & 533.33 & 96175 & 400.73 \\
\hline $30-16$ & 266.55 & 499 & 534.17 & 183990 & 368.72 & 960.26 \\
\hline 31 and more & 506.00 & 980 & 516.33 & 347150 & 354.23 & 686.07 \\
\hline total & 900.55 & 1719 & 1583.83 & 627315 & 1123.68 & 2397.7 \\
\hline
\end{tabular}

Source: Done by the researcher depending on the questionnaires.

\section{1- The productivity costs of wheat crop:}

The fixed and variable costs of wheat production were studied for showing the importance of each item of these costs items, as follow:

A- The Fixed costs : they are the costs that don't change with production level change (Al-Izi ,2002), they reached 317970.12 thousand dinars in the studied sample and they distributed among family work items that dominated on the most of the fixed costs about $67.08 \%$ while the other ratios were distributed between capital interest with $\% 27.51$ and land rent $(5.41 \%)$, the family labordomination of this high ratio and weakness of the other ratios may be due to that most of the used possessions are contracts and to the low loaned moneys and more than $40 \%$ of the fixed costs gone to the second group as it is shown in table -3-.

Table(3). fixed costs items and their relative importance ability thousand dinars

\begin{tabular}{|c|c|c|c|c|c|c|c|c|}
\hline $\begin{array}{l}\text { Possession } \\
\text { onum }\end{array}$ & $\begin{array}{l}\text { Family } \\
\text { labor }\end{array}$ & $\%$ & Land rent & $\%$ & $\begin{array}{l}\text { Capital } \\
\text { interest }\end{array}$ & $\%$ & $\begin{array}{l}\text { total Fixed } \\
\text { costs }\end{array}$ & $\%$ \\
\hline $15-1$ & 6171 & 28.93 & 240 & 13.96 & 4047.60 & 46.27 & 10458.60 & 32.89 \\
\hline $30-16$ & 10370 & 48.61 & 499 & 29.03 & 1961.76 & 22.43 & 12830.76 & 40.35 \\
\hline $\begin{array}{ll}31 & \text { and } \\
\text { more } & \end{array}$ & 4790 & 22.46 & 980 & 57.01 & 2737.76 & 31.30 & 8507.76 & 26.76 \\
\hline total & 21331 & 100 & 1719 & 100 & 8747.12 & 100 & 31797.12 & 100 \\
\hline $\begin{array}{l}\text { Total of } \\
\text { TFC } \%\end{array}$ & 67.08 & & 5.41 & & 27.51 & & & \\
\hline
\end{tabular}

Source :Done by the researcher depending on the questionnaires

* Calculated interest on Cabital $8 \%$.

\section{B- The variable costs:}

They are the costs of the variable factors that change with the productivity quantity change that may reach to zero if the production process stopped. Table -4- explains that the biggest ratio of the variable costs were gone to the fertilization that reached $46.66 \%$ of the total variable costs on sample level followed by the cost of seeds in its relative importance and they reached $26.08 \%$ after it the mechanical work costs that included plowing, smoothing and furrowing and, also harvest that took on $20.46 \%$ of the total variable costs on sample level but there were variation between group and other and the first group got the largest share, that indicates on experience and interest variation on how to deal with land element after the mechanical work the crop transport costs and their low ratio $(6.80 \%)$ attributable to small distance between 
the farm and centers of marketing, that may be attributed to the given work costs in the sample do not exist due to that the cultivated areas were not relatively large and they are managed by the family persons.

Table -4- variable costs items and their importanceability thousand dinars.

\begin{tabular}{|c|c|c|c|c|c|c|c|c|c|c|}
\hline $\begin{array}{l}\text { possession } \\
\text { donum }\end{array}$ & seeds & Perc. & fertilizer & Perc. & $\begin{array}{l}\text { Mechanical } \\
\text { work }\end{array}$ & Perc. & $\begin{array}{l}\text { Yield } \\
\text { transport }\end{array}$ & Perc. & $\begin{array}{l}\text { total Variable } \\
\text { costs }\end{array}$ & Perc. \\
\hline $15-1$ & 7380 & 27.40 & 14708 & 30.52 & 2541 & 12.02 & 546 & 7.78 & 25175 & 24.38 \\
\hline $30-16$ & 7772.5 & 28.86 & 10219.1 & 21.21 & 9102 & 43.07 & 2167 & 30.87 & 29260.6 & 28.33 \\
\hline 31 and more & 11777.5 & 43.74 & 23260.9 & 48.27 & 9491 & 44.91 & 4306 & 61.35 & 48835.4 & 47.29 \\
\hline total & 26930 & 100 & 48188 & 100 & 21134 & 100 & 7019 & 100 & 103271 & 100 \\
\hline$\%$ of TVC & 26.08 & & 46.66 & & 20.46 & & 6.80 & & & \\
\hline
\end{tabular}

Source :Done by the researcher depending on questionnaires .

\section{3- Average Costs:}

They are costs of production of one unit or average costs for each of production unit, averages of total, variable and fixed costs may be estimated by divided them respectively on total of the production units. It may be noticed that averageof total costs were high in starting of production and it decreases with productionincrease , while the average of the variable costs are positively related with production quantity.

Table-5- The total, variable and fixed costs and their averages for production of ton of wheat ability thousand dinar.

\begin{tabular}{|l|l|l|l|l|l|l|l|}
\hline $\begin{array}{l}\text { POSSISSION } \\
\text { Donum) }\end{array}$ & TVC & AVC & TFC & AFC & TC & $\begin{array}{l}\text { AC Production } \\
\text { ton }\end{array}$ & $\begin{array}{l}\text { Ac } \\
\text { (donum) }\end{array}$ \\
\hline $15-1$ & 25175 & 196.68 & 10458.60 & 81.71 & 35633.6 & 278.39 & 148.47 \\
\hline $30-16$ & 29260.6 & 109.78 & 12830.76 & 48.14 & 42091.36 & 157.91 & 84.35 \\
\hline 31 and more & 48835.4 & 96.51 & 8507.76 & 16.81 & 57343.16 & 113.33 & 58.51 \\
\hline TOTAL & 103271 & 114.68 & 31797.12 & 35.31 & 135068.12 & 149.98 & 78.57 \\
\hline
\end{tabular}

Source: Done by the researcher depending on the questionnaires.

Decline of the average of variable costs on the last group may be attributed to use of mechanical labor which managed by family farm and going away from labor wages because as it was mentioned lastly that the farms are being managed by the family persons. Average of the fixed costs decreased with increase of production (douglas,B.2007) (Table-5-).

Table(5) shows that total cost average of production of one ton of wheat was 78.57 thousand dinar and the fixed costs average of production of one ton of wheat on sample level was 35.31 thousand dinars . It was clear that these averages differ from group to other and fixed and total averages increased in the first groups and decreased with increase the cultivated areas, theses agree with the economical theory that say that there are declines in total and fixed costs averages in the large areas in when the volume availabilities cause decrease of cost average of production unit with farm size expansion. It is worth mentioning that the variable costs was $76.46 \%$ of the total costs and the fixed costs was $23.54 \%$ of it.

\section{Second : the economic efficiency criteria:}

When the last mentioned economic efficiency criteria were applied, we got to the following results.

\section{1- The profit:}

It is the difference between the total revenues and total costs and the sample gave 492246.88 thousand dinars profit and it differed between group and other. It was at maximum at third group to $58.87 \%$ and decreased at the second group to $28.83 \%$ while in the first group, it included $12.30 \%$ of profits . The profit averagegot by the farmer and donum profit average, as it is shown in table(6), were low in the small groups and then increased in the large groups and reached its maximum value in the last group.

Table : (6) Profit ,average profit and net income in the sample (thousand dinars)

\begin{tabular}{|l|l|l|l|l|l|l|l|}
\hline $\begin{array}{l}\text { Groups } \\
\text { (donum) }\end{array}$ & profit & Perc. & $\begin{array}{l}\text { Average } \\
\text { donum profit }\end{array}$ & $\begin{array}{l}\text { Average } \\
\text { farmer profit }\end{array}$ & Net income & $\begin{array}{l}\text { Perc. } \\
\text { one } \\
\text { donum }\end{array}$ \\
\hline $15-1$ & 60541.4 & 12.30 & 252.26 & 1891.92 & 54370.4 & 11.54 & 226.17 \\
\hline $30-16$ & 141898.64 & 28.83 & 284.37 & 7468.35 & 13128.64 & 27.93 & 263.58 \\
\hline 31 and more & 289806.84 & 58.87 & 295.72 & 13800.33 & 285016.84 & 60.53 & 290.83 \\
\hline TOTAL & 492246.88 & 100 & & & 470915.88 & 100 & \\
\hline
\end{tabular}

Source: Done by the researcher depending on the questionnaires . 


\section{2- Net income:}

It is the total incomes minus total costs except the family work. The income net concept differs than the economical profit concept (Al-Izi 1989: 138 ; Al-Mashhadani, 2002: 36). International experimentally approved that the net income depends primarily on farm size and it increases with increasing the cultivated areas and farm size, as it is clear in the research sample that it had a net income reached 470915.88 thousand dinars and it decreased in the first group and then increased in the second group that contributed with $27.93 \%$ of the net income on the sample level then followed by the third group (60.53\%) of the net income,Table 6.

\section{3- Returns labor and management farming:}

Through application of return to labor, it was indicated that all of the group gave positive return of work reached on the sample level to 462078.8 thousand dinars and it varied from group to other, and the third group got the larger share . The one donum gave areturn to labor 268.8 thousand dinars, returns to farming management also explained a positive returns in all the groups and it was at sample level 295680.3 thousand dinars, while the one donum got returns to farming management near to 172 thousand dinars table, 7 .

\section{4- Return dinar investor:}

When this criteria is applied, then all the studied groups gave good economic efficiency as long the return to cost was larger than one . It reached at sample level to 4.6 dinar, while at group levels it started with 2.7 dinar in the first group and reached its maximum range (6.1) Dinar in the last group and this is considered reward and financial success for production units Table-7.

\section{5- Pay back Period and Break-Even Point:}

Period of recovery of the capital of production units was low for the production units, it started at 0.6 year and decreased more in the second group to 0.3 year and then to 0.2 in the third group. This time detailed is considered encouraging, it is good period than period of crop stay in the field which was between 6-7 months . The third group gave best period 0.20 and it is another indicator provides priority of the big produced possessions of wheat crop.

The capital recovery may be return through short time due to the big revenues that may be got by the producer and it is financially successes of the production units. The Break-Even point were 18.85, 15.09 and 14.43 tons in the first, second and third groups respectively Table7.

Table (7): The economic efficiency indicators of the research sample.

\begin{tabular}{|l|l|l|l|l|l|}
\hline $\begin{array}{l}\text { Possession } \\
\text { (donum) }\end{array}$ & $\begin{array}{l}\text { Returns to Labor } \\
\text { Thous./din. }\end{array}$ & $\begin{array}{l}\text { Returns to } \\
\text { management Farm } \\
\text { Thous./din. }\end{array}$ & $\begin{array}{l}\text { Return of dinar } \\
\text { investor }\end{array}$ & $\begin{array}{l}\text { Pay Period /year } \\
\text { Back }\end{array}$ & $\begin{array}{l}\text { Break-Even point } \\
\text { /Ton }\end{array}$ \\
\hline $15-1$ & 50232.8 & 44061.8 & 2.7 & 0.66 & 18.85 \\
\hline $30-16$ & 129566.9 & 119196.88 & 4.4 & 0.32 & 15.09 \\
\hline 31 and more & 282279.1 & 277489.1 & 6.1 & 0.20 & 14.43 \\
\hline TOTAL & 462078.8 & 295680.3 & 4.6 & & \\
\hline
\end{tabular}

Source: Done by the researcher depending on the questionnaires .

\section{Third: The Stochastic Frontier Production Function (SFPF) :}

The agricultural economists realized importance of Cop Douglas function and emphasized the simplity of its determination, but it is limited so they try to find other functions, such as production function with randomized limits (Debertin 2012) for study production efficiency of sectors that suffer from problems and large variance in data, as it is the case in the agricultural sector. It is superior compared with other functions and it characterized by its wider distribution and may be known in technical efficiency determination . it characterized as its general formula may separate the residual into two parts that had a covariance equal to zero and the first part represents the non-efficient case and the second part represents other mistakes sources (Radam et all ,2008).

For determination of this function, it is transformed to transcendental logarithmic function that have the following formula .

Lny $=b_{0}+b_{1} \operatorname{LnI}+b_{2} \operatorname{Lnk}+b_{3}(L n I)^{2}+b_{4}(\text { Lnk })^{2}+b_{5} \operatorname{LnlLnk}$

$\mathrm{Y}=$ the produced quantity of wheat crop (ton)

$\mathrm{L}=$ labor hours (hour)

$\mathrm{K}=$ the capital (thousand dinars)

This model was determined by the maximum Likelihood method and through it. We can get the non- negative rests values (ui) . This method is characterized by that its determinations had theoretical properties stronger than small squares determinations properties, so the form parameters were got by using three methods ML, COLS and OLS,Table-8. 
The economic efficiency of wheat farms in Baghdad Province ( Abu-Ghraib),(In Iraq - 2015)

Table(8).The logarithmic transcendental production function according to the Stochastic frontier analysis.

\begin{tabular}{|l|l|l|l|}
\hline ML & COLS & OLS & Coefficient \\
\hline $0.137-$ & $0.136-$ & $0.137-$ & B 0 \\
\hline 0.366 & 0.366 & 0.366 & B1 \\
\hline $0.643-$ & $0.643-$ & 0.643 & B2 \\
\hline $0.125-$ & $0.125-$ & $0.125-$ & B3 \\
\hline 0.327 & 0.327 & 0.327 & B4 \\
\hline $0.248-$ & $0.248-$ & $0.248-$ & B5 \\
\hline-0.673 & & -0.673 & LL FUNCTION \\
\hline
\end{tabular}

Source: Done by the researcher depending on the questionnaires .

It is shown from Table (8) that the fixed part or the interrputed part had the same value in the least squares method and the maximum likelihood method and its value was approximate in the corrected least squares method and the labor signal was positive in the three methods and it is economically logic, when the labor increases $10 \%$ ratio, the production increases $3.6 \%$, while the capital signal was negative and not satisfied with the economic logic, it mean if capital increases $10 \%$ the production decrease $6.4 \%$ because that the capital increase represented by using new crops varieties or new technological ways, here we had negative effect on production due to connection of the capital by the cultivated areas. The most cultivated areas in the study sample were small and cannot get advantage from the new technology and when they were used then the using was not efficient . The partial elasticity between labor and capital was negative (-0.248) and it emphasized the integrated relation between labor and capital, that is also capable in the agricultural production when there was not clear replacement . and if it present, it would be connected to large extent with family labor due to the masked unemployment. Due to efficiency of the determined parameters of the maximum likelihood method for mistake limits and small size for society determinations in which they were taken, so the significantly was not important as it was in OLS and the logarithmic function for maximum likelihood was 0.67 and refers to presence of technical variations that effects negatively of the randomized variable and then in technical efficiency. Table (9) explained use of the logarithmic transcendental production function in estimate technical efficiency according to the stochastic frontier analysis model by using Frontier program.

Table (9): the technical efficiency according to SFA way.

\begin{tabular}{|c|c|c|c|c|c|c|c|c|c|c|c|}
\hline $\begin{array}{l}\text { far } \\
\mathrm{m}\end{array}$ & $\begin{array}{l}\text { Technical } \\
\text { efficienc } \\
\mathrm{y}\end{array}$ & farm & $\begin{array}{l}\text { Technical } \\
\text { efficienc } \\
\mathrm{y}\end{array}$ & Farm & $\begin{array}{l}\text { Technical } \\
\text { efficienc } \\
\mathrm{y}\end{array}$ & Farm & $\begin{array}{l}\text { Technical } \\
\text { efficienc } \\
\mathrm{y}\end{array}$ & Farm & $\begin{array}{l}\text { Technical } \\
\text { efficienc } \\
\mathrm{y}\end{array}$ & Farm & $\begin{array}{l}\text { Technical } \\
\text { efficiency }\end{array}$ \\
\hline 1 & 0.99 & 13 & 0.99 & 25 & 0.99 & 37 & 0.99 & 49 & 0.99 & 61 & 0.99 \\
\hline 2 & 0.99 & 14 & 0.99 & 26 & 0.99 & 38 & 0.99 & 50 & 0.99 & 62 & 0.99 \\
\hline 3 & 0.99 & 15 & 0.99 & 27 & 0.99 & 39 & 0.99 & 51 & 0.99 & 63 & 0.99 \\
\hline 4 & 0.99 & 16 & 0.99 & 28 & 0.99 & 40 & 0.99 & 52 & 0.99 & 64 & 0.99 \\
\hline 5 & 0.99 & 17 & 0.99 & 29 & 0.99 & 41 & 0.99 & 53 & 0.99 & 65 & 0.99 \\
\hline 6 & 0.99 & 18 & 0.99 & 30 & 0.99 & 42 & 0.99 & 54 & 0.99 & 66 & 0.99 \\
\hline 7 & 0.99 & 19 & 0.99 & 31 & 0.99 & 43 & 0.99 & 55 & 0.99 & 67 & 0.99 \\
\hline 8 & 0.99 & 20 & 0.99 & 32 & 0.99 & 44 & 0.99 & 56 & 0.99 & 68 & 0.99 \\
\hline 9 & 0.99 & 21 & 0.99 & 33 & 0.99 & 45 & 0.99 & 57 & 0.99 & 69 & 0.99 \\
\hline 10 & 0.99 & 22 & 0.99 & 34 & 0.99 & 46 & 0.99 & 58 & 0.99 & 70 & 0.99 \\
\hline 11 & 0.99 & 23 & 0.99 & 35 & 0.99 & 47 & 0.99 & 59 & 0.99 & 71 & 0.99 \\
\hline 12 & 0.99 & 24 & 0.99 & 36 & 0.99 & 48 & 0.99 & 60 & 0.99 & 72 & 0.99 \\
\hline & & & & & & & & & & mean & 0.99 \\
\hline
\end{tabular}

Source : Done by the researcher depending on the questionnaires.

The technical efficiency average value on sample level was 0.99 , that means that the farmers were capable of increasing their wheat production by only $1 \%$ without increase of the used resources quantity, that means also the farm sample has high efficiency in using the available resources and the deviation of the actual production oven the optimum production is only $1 \%$ and all the farms are near from production on the productionpossibility curve. All of the farms had same technical efficiency (0.99) and that confirms that the wheat farmers in the research sample have high management efficiency in using the available resources.

\section{Conclusions And Recommendations}

It may be concluded of rejection of the research hypothesis that says the wheat cultivation was neither worthwhile nor profitable from economic point of view to the farmer, all the research sample farmers got good profits. The most expanding groups are those had between (1-15) donum in the farmers number and this group fixed of $44.4 \%$ of the farmers who included in this study.

In area parameter, the group with 31 donum and more had the larger ratio (57\%) of the wheat cultivated areas in study region. The family labor had the larger contribution ratio in the fixed costs and all the 
economic efficiency parameters were positive, all farm labor and farming management returnes were rewarding in the farmers sample generally. Most of the farmers don't have machinery due to small size of the cultivated areas ,so they had to rent the tractors and harvesters. The farms sample closes to the production possibilities curve, and all farms had high technical efficiency in which the average of it on sample level was $0.99 \%$ and this indicates that wheat cultivators in the research sample had high management efficiency in using the available resources.

It may be recommended in agriculture expanding and concentrated in growing wheat in large areas from 31 donum and more, as the used criteria provide best donum profit . It may be also recommended to increase the agricultural loans and facilitate the ways of getting them in order to make using machinery and expanding the agriculture generally possible .The research results may recommend to follow the new scientific ways in cultivation and irrigation and leave the classical ways for getting the optimum advantage of the available agricultural resources .

\section{References}

[1]. AIazzi, J.M. 1988. Farms management between theory and practice, Higher Education Press, Baghdad University. 233 pp.

[2]. AIazzi, J.M. 1989. Introduc on of agriculture survey in the evaluation of higher education and research projects. Baghdad University.

[3]. AIazzi, J.M. 2002. Ways to established modern techniques in cooperative farms. Iraqi Agric. Sci. J., 33(5): $233-240$.

[4]. Qaisi, I. 2009. Farms income of Pistachio field in Diyala province. MSc Thesis, College of Agriculture, University of Baghdad.,

[5]. Al-Mashhadani, A. 2002. Financial calendar for the production of broiler chickens projects fields. Iraqi Journal of Agricultural Sciences - 33. folder number 4. Pp. 213-222.

[6]. AL-Samurai, H.A. 1984. Farming work management, University of Baghdad press. p88.

[7]. Debertin,D.L. 2012. Agricultural production economic. Second ed., MacMillan publishing Com. USA. pp -366.

[8]. Donna, C. S. Summers . 2009. Quality management . Pearson education International. $2^{\text {nd }}$ ed. pp-188.

[9]. Douglas, B. and M. D. M. Whinston. 2007.Microeconomic. Mcgraw.Hill.

[10]. Extension sheet (Wheat cultivation technology) .2011. Agricultural extension and cooperation insinuation .

[11]. FAO, Food and Agricultural International Organization .2011.

[12]. Faris, A.M.2006. Use Primary estimaters determinations of average cost production of one donum of wheat crop to limit the price extent of production , 37(2): 37-42

[13]. Farrell, M. J.1957. The measurement of productive efficiency . Journal Statistical Society. pp-120.

[14]. Radam, A, M. and A. M. Abdula.A. 2008. Technical efficiency of small and average enterprise Malaysia, A stochastic Frontier production model. Int . Journal of Economics and Management ,2(2):395-408.

[15]. Solis,D. B. Bravo-Ureta, and Quiroyal. 2009. Technical efficiency among Peanut farmers participating in natural America. J. Agri. , Econ 60 